\title{
Skrining Kanker Serviks dengan Pemeriksaan Pap Smear di Puskesmas Tanah Kali Kedinding Surabaya dan Rumah Sakit Mawadah Mojokerto
}

\author{
Gondo Mastutik, Rahmi Alia, Alphania Rahniayu, Nila Kurniasari, Anny Setijo Rahaju, \\ Sjahjenny Mustokoweni \\ Departemen Patologi Anatomi, Fakultas Kedokteran, Universitas Airlangga
}

\begin{abstract}
ABSTRAK
Tujuan: Penelitian ini bertujuan untuk mengetahui prevalensi lesi prekanker serviks dengan cara melakukan skrining kanker serviks menggunakan pemeriksaan Pap smear.

Bahan dan Metode: Penelitian ini merupakan penelitian observasional deskriptif dengan metode pendekatan cross sectional yang dilakukan pada 140 wanita, terdiri dari 90 orang dari Puskesmas Tanah Kali Kedinding Surabaya, dan 50 orang dari Rumah Sakit Mawadah Mojokerto, dengan usia 20-70 tahun. Pemeriksaan spesimen sitologi serviks dengan pengecatan Papaniculaou dan klasifikasi hasil pemeriksaaan sitologi berdasar-kan klasifikasi Papaniculaou dan sistim Bethesda. Pemeriksaan inspeksi visual asam asetat (IVA) adalah metode lain untuk skrining kanker serviks dilakukan dengan mengoleskan asam asetat $5 \%$ pada area serviks dan melakukan pengamatan satu menit kemudian.

Hasil: Hasil pemeriksaaan Pap smear menunjukkan Papaniculaou kelas I (sama dengan normal pada klasifikasi sistim Bethesda) yaitu $12.1 \%$, kelas II (sama dengan NILM pada klasifikasi sistim Bethesda) yaitu 86, 4\%, dan kelas III (sama dengan LSIL pada klasifikasi sistim Bethesda) yaitu 1,4\%. Hasil pemeriksaan IVA menunjukkan $6,43 \%$ positif dan $93,57 \%$ negatif. Hasil pemeriksaan IVA positif terdapat pada 9/140 orang yang merupakan proses keradangan dan infeksi, bukan merupakan lesi prekanker.

Simpulan: Prevalensi lesi prekanker yaitu 1,4\%. Pemeriksaan IVA menunjukkan hasil positif semu yang disebabkan oleh proses radang atau infeksi pada serviks.
\end{abstract}

Kata kunci: skrining, pap smear, IVA, prevalensi lesi prekanker serviks.

\begin{abstract}
Objectives: This study aims to determine the prevalence of precancerous lesions of the cervix by screening for cervical cancer with a Pap smear test.

Materials and Methods: This study is an observational study with cross sectional method performed on 140 women consist of 90 persons from the health center Tanah Kali Kedinding Surabaya, and 50 persons Mawadah Hospital Mojokerto, aged 20-70 years. Examination of cervical cytology specimens with Papaniculaou staining and classification of cytologic examination results based on classification of Papaniculoau and The Bethesda system. Examination of visual inspection of acetic acid (VIA) is done by applying a $5 \%$ acetic acid in the cervical area and observed within one minute.

Results: Pap smear examination results showed Papanicolaou class I (same with normal smear in The Bethesda system) is $12.1 \%$, class II (same with NILM in The Bethesda system) is 86, $4 \%$, and class III (same with LSIL in The Bethesda system) ie, $1,4 \%$. The examination results of IVA showed $6.43 \%$ positive and $93.57 \%$ negative. Positive VIA test results contained in 9/140 person are inflammation and infection process, not a precancerous lesion.

Conclusion: The prevalence of precancerous lesions is $1.4 \%$. IVA examination showed false positive results caused by inflammation or infection of the cervix.
\end{abstract}

Keywords: screening, pap smear, IVA, precanceruos lesion cervix

Correspondence: Gondo Mastutik, Departemen Patologi Anatomi, Fakultas Kedokteran, Universitas Airlangga, Jl. Prof. Dr. Moestopo 47, Surabaya 60131, Telp 62-31-5020251psw 182, Fax 62-31- 5026333, E-mail: gondomastutik@ gmail.com

\section{PENDAHULUAN}

Kanker serviks merupakan kanker terbanyak keempat pada wanita di seluruh dunia dan pada tahun 2012 terdapat 527.624 kasus baru. Kematian akibat kanker serviks adalah $7,5 \%$ dari semua kematian akibat kanker pada wanita dan hampir 50\% dari kasus baru kanker serviks yang mengalami kematian yaitu 265.653 pada tahun 2012. Hampir sembilan dari sepuluh $(87 \%)$ kematian akibat kanker serviks terjadi di daerah tertinggal. ${ }^{1}$ Indonesia memiliki populasi 89.070.000 wanita berusia sama dengan dan lebih dari 15 tahun yang berisiko terkena kanker serviks. Kanker serviks di Indonesia menempati urutan kedua setelah kanker payudara. Kejadian kanker serviks di Indonesia (update terakhir 14 Jul 2014) yaitu 20.928 kasus baru didiagnosis setiap tahun dan paling sering terjadi pada wanita berusia 15-44 tahun. Kematian akibat kanker serviks di Indonesia yaitu 9.498 yang terjadi pada tahun $2012^{2}$

Kanker serviks termasuk penyakit yang dapat dicegah karena mempunyai fase prakanker yang cukup panjang. Kejadian kanker serviks membutuhkan proses dari 3 sampai 20 tahun yang dimulai dari infeksi HPV sampai menjadi kanker. ${ }^{3}$ Kanker serviks merupakan penyakit yang diam pada tahap prakanker dan kanker awal tidak menimbulkan gejala atau keluhan. Oleh karena itu, skrining rutin diperlukan untuk mendeteksi secara dini kanker serviks. Program skrining sitologi serviks atau yang lebih popular dikenal dengan sebutan Papanicolaou (pap) smear sangat membantu menurun-kan insiden kanker serviks. Pemeriksaan Pap smear tidak hanya berguna untuk deteksi kanker serviks pada 
stadium rendah, tetapi juga efektif untuk mendeteksi lesi prakanker sehingga dapat menurunkan mortalitas akibat kanker dan meningkatkan angka ketahanan hidup. ${ }^{3}$ Pada lesi prakanker tersebut masih dapat diberikan terapi yang mudah dan cukup efektif untuk mencegah perkembangan kearah keganasan serviks. ${ }^{4}$ Selain itu pemeriksaan menggunakan metode inspeksi visual dengan asam asetat (IVA) juga merupakan suatu upaya deteksi dini kanker serviks secara sederhana dengan melakukan inspeksi atau melihat keadaan mulut rahim dengan mata telanjang kemudian melakukan pengolesan serviks dengan menggunakan asam asetat 5\% dan setelah sekitar sepuluh detik dilakukan observasi terhadap perubahan yang berupa ada atau tidak ada warna memutih pada serviks yang mncerminkan kondisi lesi prakanker serviks. Fase ini merupakan tujuan utama dari skrining kanker serviks. Keuntungan dari metode ini adalah sederhana, cepat, mudah, murah, tidak nyeri, dan hasil langsung bisa dilihat tanpa intepretasi laboratorik. Metode ini dapat dikerjakan pada low resource setting sehingga diutamakan untuk golongan masyarakat miskin, masyarakat terpencil yang sulit mendapatkan akses pelayanan kesehatan, dan dapat dikerjakan oleh bidan di puskesmas.

Program skrining kanker serviks dengan Pap smear telah dilakukan di banyak negara maju dan berhasil menurunkan jumlah insiden kanker serviks di negara maju tersebut. ${ }^{5}$ Meskipun program skrining telah berjalan dengan baik di Amerika Serikat, tetapi diperkirakan 30\% dari kasus kanker kanker serviks terjadi pada wanita yang tidak pernah menjalani Pap smear. ${ }^{4}$ Program skrining di negara berkembang tidak berjalan rutin atau bahkan tidak dilakukan. Wanita di negara berkembang yang melakukan Pap smear yaitu hanya sekitar kurang dari 5\% seluruh total populasi wanita dan hampir 60\% dari kasus kanker serviks di negara berkembang terjadi pada wanita yang tidak pernah melakukan Pap smear. ${ }^{4}$ Oleh karena itu perlu dilakukan skrining kanker serviks dengan pemeriksaaan Pap smear untuk mendapatkan data kelainan sitologi serviks yang meliputi data normal smear, proses keradangan, low grade intraepithelial lesion (LSIL), high grade intraepithelial lesion (HSIL), carcinoma insitu, dan carcinoma invasive serta IVA untuk mendapatkan data kelainan serviks.

\section{BAHAN DAN METODE}

Penelitian ini merupakan penelitian observasional deskriptif dengan metode pendekatan cross sectional yang bertujuan untuk mendapatkan data kelainan sitologi yang meliputi data normal smear, proses keradangan, LSIL, HSIL, carcinoma insitu, dan carcinoma invasive dengan pemeriksaan Pap smear dan kelainan serviks dengan pemeriksaan IVA. Populasi pada penelitian ini adalah wanita yang tinggal di sekitar lokasi Puskesmas Tanah Kali Kedinding Surabaya dan Rumah Sakit Mawadah Mojokerto. Sampel penelitian adalah 140 wanita yang terdiri dari 90 orang dari Puskesmas Tanah Kali Kedinding Surabaya, dan 50 orang Rumah Sakit Mawadah Mojokerto, berusia antara 20-70 tahun yang mengikuti kegiatan pengabdian kepada masyarakat. Peserta penelitian datang ke lokasi penelitian tanpa keluhan dan ingin mengetahui status kesehatan organ kelamin wanita dengan kriteria tidak sedang hamil, tidak sedang menstruasi, tidak melakukan hubungan seksual 24 jam sebelum pengambilan pemeriksaan, dan bebas obat-obatan per vagina selama 7 hari, kemudian dilakukan pengambilan spesimen sitologi serviks dan pemeriksaaan IVA.

Spesimen sitologi serviks dilakukan pengecatan Papanicolau di Departemen Patologi Anatomi Fakultas Kedokteran Universitas Airlangga Surabaya dan pembacaan oleh screener dan dokter Spesialis Patologi Anatomi. Hasil pemeriksaan sitologi didiagnosis berdasarkan klasifikasi Papanilculoau dan sistim Bethesda. Pemeriksaan IVA dilakukan dengan cara melakukan inspeksi atau melihat keadaan serviks dengan mata telanjang kemudian mengoleskan asam asetat 3-5\% pada serviks dan observasi setelah sekitar sepuluh detik terhadap perubahan yang berupa ada atau tidak ada warna memutih pada serviks. Interpretasi hasil dari metode IVA adalah jika terdapat warna putih berarti tes IVA positif karena terdapat white epithelium yang mencerminkan adanya kondisi lesi pra kanker. Jika tidak terdapat warna putih maka tes IVA negatif. Data yang terkumpul dianalisis berdasarkan presentase kejadian dari hasil pemeriksaan Pap smear dan IVA.

\section{HASIL DAN PEMBAHASAN}

Skrining sitologi serviks dengan pemeriksaaan Pap smear diikuti oleh 140 wanita, terdiri dari 90 orang dari Puskesmas Tanah Kali Kedinding Surabaya dan 50 orang Rumah Sakit Mawadah Medika Mojokerto. Peserta kegiatan berusia antara 20 sampai 70 tahun, yang paling banyak yaitu berusia antara 41-50 tahun (Tabel 1).

Pengambilan spesimen untuk pemeriksaan Pap smear dan pengolesan asam asetat untuk pemeriksaan IVA dilakukan pada semua peserta penelitian. Hasil pemeriksaan Pap smear pada penelitian ini mendapatkan gambaran normal smear, negative intraepithelial lesion of malignancy (NILM) (Gambar 1), infeksi bakteri vagina, infeksi trichomonas, infeksi jamur (Gambar 2) dan LSIL (Gambar 3). Normal smear yaitu tampak sebaran dan kelompok epitel squamous superficial dan 
intermediate, sel berbentuk poligonal, inti kecil, sitoplasma luas kemerahan. Normal atropic smear yaitu tampak sebaran sel epitel quamous basal dan parabasal, sel berbentuk bulat dengan inti bulat. NILM yaitu tampak sebaran dan kelompok epitel squamous superficial dan intermediate di antara sebaran luas sel radang Polymorphonuclear (PMN) dan Mononuclear (MN), sel epitel superficial berbentuk poligonal, inti kecil, sitoplasma luas kemerahan.

Tabel 1. Karakteristik umur peserta penelitian

\begin{tabular}{cc}
\hline Umur (tahun) & Jumlah (orang) \\
\hline $21-30$ & 20 \\
$31-40$ & 46 \\
$41-50$ & 49 \\
$51-60$ & 23 \\
$61-70$ & 2 \\
\hline Jumlah & 140 \\
\hline
\end{tabular}

Infeksi bakteri vagina yaitu tampak sel squamous yang tertutup oleh selapis bakteri (clue-cells) yang mengaburkan membran sel. Infeksi Trichomonas vaginalis, tampak Trichomonas vaginalis (dalam sitoplasma epitel superficialis), organisme berbentuk buah seperti buah pear dengan inti terletak eksentrik, sitoplasma eosinofilik bergranular. Infeksi jamur, tampak spora jamur berbentuk bulat, berukuran kecil dikelilingi oleh hallo yang jernih pada pewarnaan Papaniculaou, tampak hifa berbentuk seperti batang, warna abu-abu.

Klasifikasi lesi prakanker serviks telah berkembang dari waktu ke waktu. Sistem klasifikasi yang terlama yaitu Papaniculoau berupa displasia ringan, displasia sedang, dan displasia berat atau karsinoma in situ, kemudian diikuti dengan klasifikasi sistim Bethesda berupa cervical intraepithelial neoplasia (CIN) dengan kesetera-an yaitu displasia ringan disebut CIN I, displasia sedang disebut CIN II, dan displasia berat disebut CIN III. Manajemen penanganan pasien terkait dengan derajat displasia maka dilakukan klasifikasi sistim baru yaitu CIN I berganti nama menjadi low grade squamous intraepithelial lession (LSIL) karena penanganan lesi prakanker hanya dengan melakukan pengamatan dan CIN II dan CIN III digabungkan menjadi satu kategori yang disebut high grade squamous intraepithelial lesion (HSIL) karena penanganan lesi prakanker dilakukan dengan pembedahan. ${ }^{4,6}$

Klasifikasi Papanicolaou yaitu Papaniculaou kelas I jika tidak terdapat sel atipik atau abnormal, Papaniculaou kelas II jika terdapat gambaran sitologi atipikal, tetapi tidak ada bukti keganasan, Papaniculaou kelas III jika terdapat gambaran sitologi berupa mencurigakan keganasan, displasia ringan sampai sedang, Papaniculaou kelas IV jika terdapat gambaran sitologi ke- ganasan dijumpai displasia berat, dan papanicolaou kelas V jika terdapat gambaran sitologi keganasan (Tabel 2).
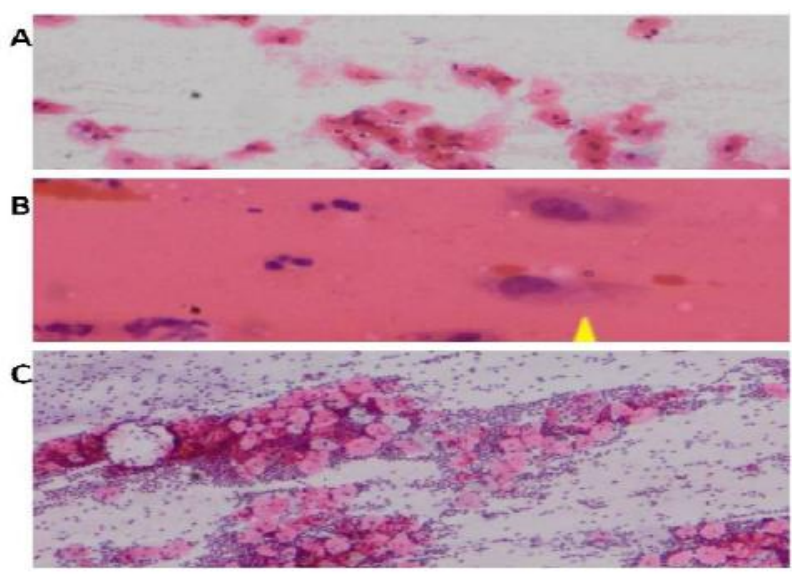

Gambar 1. Gambaran hasil pemeriksaan Pap smear yaitu normal smear (A), B. normal atropic smear (B), dan NILM (C)
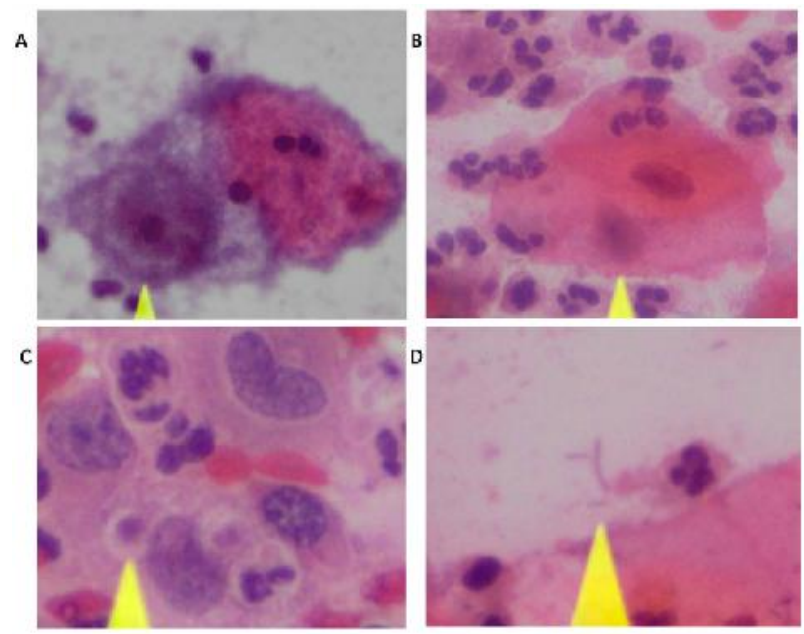

Gambar 2. Gambaran hasil pemeriksaan Pap smear pada infeksi bakteri vagina (A), infeksi Trichomonas vaginalis $(\mathrm{B})$, infeksi jamur, tampak spora jamur berbentuk bulat (C) tampak hifa berbentuk seperti batang, warna abuabu (D)

Klasifikasi sistim Bethesda 2001 yaitu normal, negatif untuk lesi intraepitel atau keganasan (NILM), sel epitel abnormal, dan perubahan yang lain (Tabel 3). NILM terdiri dari organisme dan temuan non neoplastik. Organism yaitu Trichomonas vaginalis, organisme jamur yang secara morfologi sesuai dengan candida spesies, pergeseran flora bacterial vaginosis, bakteri 
yang secara morfologik sesuai dengan spesies Actinomyces, perubahan seluler yang sesuai dengan Virus Herpes Simplex, temuan non neoplastik yaitu perubahan seluler terkait dengan keradangan, sel glandular post histrektomi, dan atrofi.

Sel epitel abnormal terjadi pada sel squamus dan sel glandular. Abnormalitas pada sel squamus yaitu atypical squamus cell (ASC), atypical squamus of undetermined significant (ASCUS), atypical squamus cell can not exclude HSIL (ASC-H), LSIL, HSIL (modifikasi CIN 2 dan CIN 3), dan squamus cell carcinoma. Abnormalitas pada sel glandular yaitu atypical glandular cell (AGC), atypical glandular cell neoplastik, endocervical adenocarcinoma in situ (AIS), dan adenocarcinoma. Perubahan lain yaitu perubahan sel endometrium pada wanita diatas umur 40 tahun. ${ }^{7}$

Tabel 2. Kriteria kelasifikasi Papanicolaou ${ }^{7}$

\begin{tabular}{cl}
\hline Kelas & \multicolumn{1}{c}{ Keterangan } \\
\hline I & Tidak ada sel atipic atau abnormal \\
II & $\begin{array}{l}\text { Gambaran sitologi atipical, } \\
\text { tetapi tidak ada bukti keganasan } \\
\text { Gambaran sitologi dicurigai keganasan, } \\
\text { displasia ringan sampai sedang }\end{array}$ \\
III & $\begin{array}{l}\text { Gambaran sitologi keganasan } \\
\text { dijumpai displasia berat }\end{array}$ \\
IV & Gambaran sitologi keganasan \\
V &
\end{tabular}

Hasil pemeriksaaan Pap smear menunjukkan Papaniculaou kelas I (sama dengan normal pada klasifikasi sistim Bethesda) yaitu 17/140 (12.1\%), kelas II (sama dengan NILM pada klasifikasi sistim Bethesda) yaitu $121 / 140$ orang $(86,4 \%$ ), dan kelas III (sama dengan LSIL pada klasifikasi sistim Bethesda) yaitu 2/140 (1.4\%) (Tabel 4). Hasil pemeriksaan Pap smear di Puskesmas Tanah Kali Kedinding menunjukkan Papaniculaou kelas I yaitu 8/90 (8,9\%), Papaniculaou kelas II yaitu 81/90 (99,9\%), dan Papaniculaou kelas III yaitu 1/90 (1,1\%). Hasil pemeriksaaan Pap smear di Rumah Sakit Mawadah menunjukkan Papaniculaou kelas I yaitu 9/50 (18\%), Papaniculaou kelas II yaitu 40/50 (80\%), dan Papaniculaou kelas III yaitu 1/50 (2\%). Hasil pemeriksaan Pap smear yang menunjukkan carcinoma in situ (sama dengan Papaniculaou kelas IV) dan carcinoma invasive (sama dengan Papaniculaou kelas V) tidak terdapat pada hasil penelitian ini (Tabel 4).

Tabel 3. The 2001 Bethesda System $^{7}$

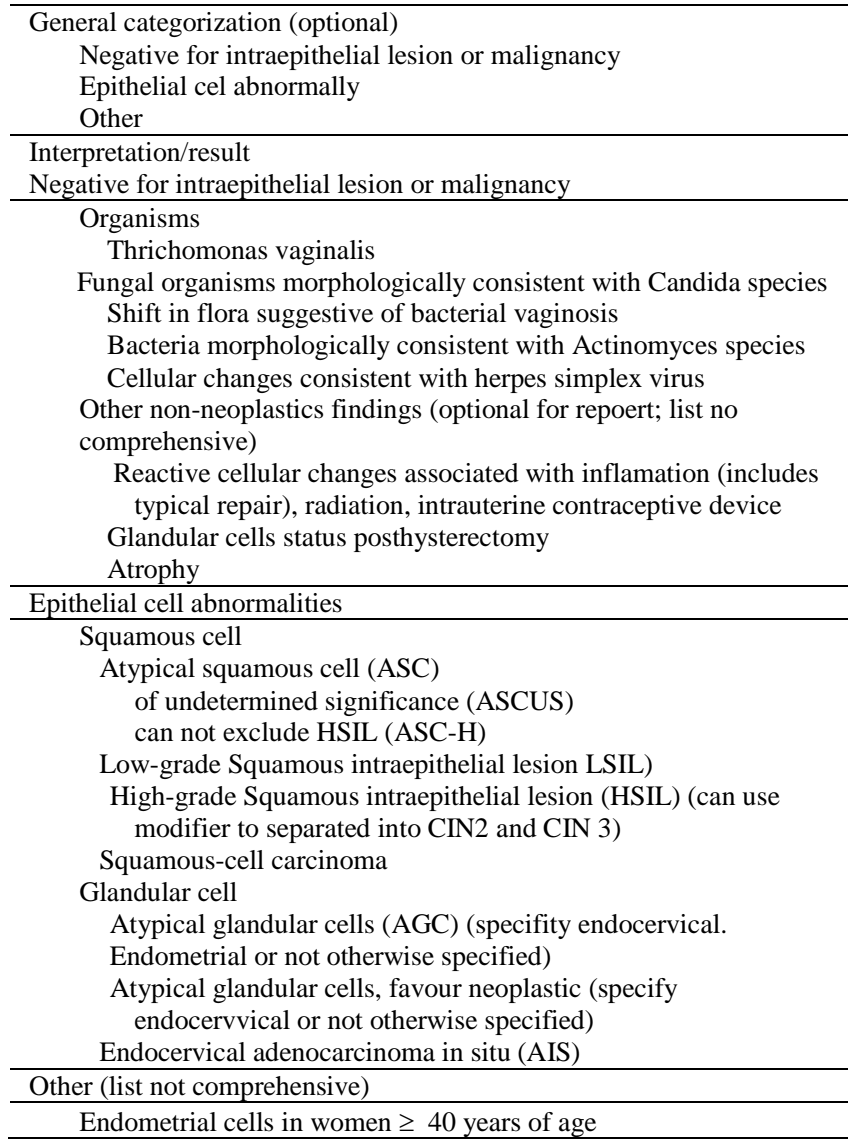

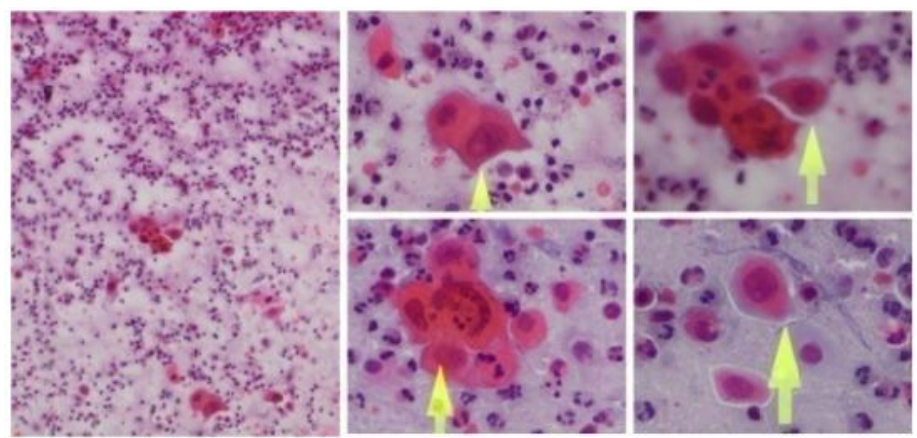

Gambar 3. Gambaran hasil pemeriksaan Pap smear pada LSIL 
Tabel 4. Hasil pemeriksaan Pap Smear Berdasarkan klasifikasi Papanicolaou dan Bethesda di Puskesmas Tanah Kali Kedinding dan Rumah Sakit Mawadah

\begin{tabular}{llcccccc}
\hline \multicolumn{1}{c}{$\begin{array}{c}\text { Klasifikasi } \\
\text { papanicolaou }\end{array}$} & $\begin{array}{c}\text { Klasifikasi } \\
\text { bethesda }\end{array}$ & Total & Persentase (\%) & Takal & Persentase (\%) & RSM & Persentase (\%) \\
\hline Kelas I & Normal & 17 & 12,1 & 8 & 8,9 & 9 & 18 \\
Kelas II & NILM & 121 & 86,4 & 81 & 90 & 40 & 80 \\
Kelas III & LSIL & 2 & 1,4 & 1 & 1,1 & 1 & 2 \\
Kelas IV & HSIL & 0 & 0 & 0 & 0 & 0 & 0 \\
Kelas V & Carcinoma & 0 & 0 & 0 & 0 & 0 & 0 \\
\hline \multicolumn{2}{l}{ Jumlah } & & 140 & & 90 & & 50 \\
\hline
\end{tabular}

Takal $=$ Tanah Kali Kedinding, RSM= Rumah sakit Mawadah, NILM= negative for intraepithelial lesion or malignancy, LSIL= low grade squamous intraepithelial lesion, HSIL= high grade squamous intraepithelial lesion

Tabel 5. Data NILM di Puskesmas Tanah Kali Kedinding dan Rumah Sakit Mawadah

\begin{tabular}{|c|c|c|c|c|c|c|}
\hline NILM & Jumlah & $\begin{array}{c}\text { Persentase } \\
(\%)\end{array}$ & Takal & $\begin{array}{c}\text { Persentase } \\
(\%)\end{array}$ & Rsm & $\begin{array}{c}\text { Persentase } \\
(\%)\end{array}$ \\
\hline \multicolumn{7}{|l|}{ A. Proses Radang Spesifik } \\
\hline Infeksi Trichomonas vaginalis & 1 & 0,7 & 1 & 1,1 & 0 & 0 \\
\hline Infeksi jamur & 22 & 15,7 & 18 & 20 & 4 & 8 \\
\hline Infeksi bacteri vaginalis & 15 & 10,7 & 14 & 15,6 & 1 & 2 \\
\hline Infeksi bakteri dan jamur & 1 & 0,7 & 0 & 0 & 1 & 2 \\
\hline B. Proses radang non-spesifik & 82 & 58,6 & 48 & 53,3 & 34 & 68 \\
\hline Total & 121 & 86,4 & 81 & 90 & 40 & 80 \\
\hline
\end{tabular}

Data tersebut menunjukkan prevalensi Pap smear abnormal yang terdiri dari LSIL, HSIL dan SCC pada populasi wanita di Surabaya dan Mojokerto $1,4 \%$ yaitu $1,1 \%$ di Puskesmas Tanah Kali Kedinding dan $2 \%$ di Rumah Sakit Mawadah. Data tersebut hanya untuk LSIL karena HSIL 0\% dan SCC 0\%. Prevalensi Pap smear abnormal pada serviks dari 4.703 sampel di Uttar Pradesh India yaitu 3,2\% yang terdiri dari atypical squamous and glandular cells of undetermined significance (ASCUS) 0,52\%, atypical squamous cellcan not exclude HSIL (ASC-H) 0,05\%, atypical glandular cells of undetermined significance (AGUS) $0,05 \%$, low-grade squamous intraepithelial lesion (LSIL) 1,36\%, high-grade squamous intraepithelial lesion (HSIL) 0,91\%, dan squamous cell carcinoma (SCC) $0,28 \%{ }^{8}$ Prevalensi LSIL di Saudi Arabia dari 5132 sampel menunjukkan Pap smear abnormal yaitu $4,7 \%$ yang terdiri dari ASCUS 2,4\%, LSIL $0,6 \%$, HSIL $0,4 \%$, AGUS $1,1 \%$. Kategori ganas yaitu SCC $0,08 \%$, adenocarcinoma insitu $0,02 \%$ dan invasive $0,04 \%$. Keganasan jenis lain yaitu $0,04 \%$ dan carcinoma neuroendocine $0,02 \%$. Studi yang kedua dilakukan dari 45.596 sampel menunjukkan prevalensi Pap smear abnormal yaitu 1,4\%. Prevalensi Pap smear abnormal pada kedua penelitian tersebut yaitu 50.728 sampel yaitu $1,6 \%{ }^{9}$ Pasien dengan hasil pap smear abnormal untuk HSIL mendapat terapi pembedahan, sedangkan LSIL dilakukan pemantauan selama 6 bulan. Hasil penelitian ini menunjukkan terdapat $1,4 \%$ sampel yang didiagnosis LSIL sehingga dilakukan pemantuan pada pasien tersebut.

NILM pada penelitian ini terdiri dari proses keradangan yaitu $39 / 140$ orang $(27,9 \%)$ yang meliputi infeksi Trichomonas vaginalis $1 / 140$ orang $(0,7 \%)$, infeksi jamur $22 / 140$ orang $(15,7 \%)$, infeksi bakteri vaginalis $15 / 140$ orang $(10,7 \%)$, infeksi bakteri dan jamur 1/140 orang $(0,7 \%)$ dan non spesifik sebanyak $82 / 140$ orang $(58,6 \%)$ (Tabel 5). Jenis infeksi spesifik pada saluran kelamin wanita di Puskesmas Tanah Kali Kedinding Surabaya yaitu infeksi Trichomonas vaginalis 1,1\% (1/90), jamur $20 \%$ (18/90), dan bakteri vaginalis $15,6 \%$ (14/90). Radang non spesifik adalah perubahan sel karena proses keradangan yang tidak menunjukkan karakteristik spesifik untuk organisme tertentu. Hasil penelitian ini untuk radang non spesifik yaitu 53,3\% (48/90). Jenis infeksi spesifik pada saluran kelamin wanita di Rumah Sakit Mawadah Mojokerto yaitu infeksi jamur $8 \%$ (4/50), bakteri vaginalis $2 \%(1 / 50)$, infeksi bakteri bersama jamur $2 \%$ (1/50), dan radang non spesifik yaitu 68\% (34/50) (Tabel 5). 
Tabel 6. Hasil pemeriksaan IVA di Puskesmas Tanah Kali Kedinding dan Rumah Sakit Mawadah

\begin{tabular}{lcc}
\hline Hasil IVA & Jumlah & Persentase (\%) \\
\hline Positif & 9 & 6,43 \\
Negatif & 131 & 93,57 \\
\hline Jumlah & 140 & 100 \\
\hline
\end{tabular}

IVA merupakan teknik yang bagus untuk skrining, sederhana, mudah, biaya murah dan mempunyai sensitifitas yang tinggi dibandingkan Pap smear, sehingga dapat digunakan sebagai teknik untuk skrining kanker serviks di daerah terpencil. ${ }^{12}$ Hal tersebut dinyatakan berdasarkan hasil penlitian yang menunjukkan bahwa pemeriksaan IVA positif pada 24/200 orang (12\%) dan hasil Pap smear abnormal 8(4\%), 5 LSIL, 2 HSIL, 1 suspek ganas. Pap smear mempunyai sensitifitas $50,1 \%$, spesifisitas $93,1 \%$, nilai prediksi positif $89,3 \%$ dan nilai prediksi negatif $65,6 \%$, sedangkan IVA mempunyai sensitifitas $90 \%$, spesifisitas $37 \%$, nilai prediksi positif $52 \%$ dan nilai prediksi negatif $81 \% .^{12}$ Teknik visualisasi langsung pada serviks dengan menggunakan asam asetat digunakan sebagai alternatif pengganti Pap smear pada negara sedang berkembang. Inspeksi visual dengan asam asetat 5\% diaplikasikan pada serviks dengan cotton swab besar dan ditunggu 3060 detik setelah pengolesan asam asetat hasil dapat dilihat. Sel dengan lesi prakanker menghasilkan protein dalam jumlah yang banyak, sehingga dengan pengolesan asam asetat akan menimbulkan warna putih, sedangkan serviks normal tanpa lesi prakanker warna tidak berubah.

Skrining dengan Pap smear mempunyai sensitifitas $84,2 \%$ dan spesifisitas $62,1 \%$, sedang pemeriksaan IVA mempunyai sensitifitas $84,2 \%$ yang sama sensitifnya dengan Pap smear dan spesifisitas 55,2\% yang lebih rendah dibandingkan dengan Pap smear. ${ }^{10}$ Penyebab hasil pemeriksaan IVA mempunyai sensitifitas yang tinggi dan spesifisitas rendah adalah proses inflamasi atau infeksi bisa menyebabkan area putih (acetowhite) pada epitel yang diolesi asam asetat, area acetowhite yang samar mungkin dinterpretasikan sebagai positif, dan skoring area acetowhite yang berbeda diinterpretasikan sebagai positif. ${ }^{10}$

IVA adalah metode yang digunakan sebagai alternatif Pap smear karena mudah dilakukan dengan biaya murah. Pemeriksaaan Pap smear membutuhkan dokter ahli patologi dan untuk mengetahui hasil pemeriksaan, pasien harus datang lagi ke dokter pemeriksa satu sampai dua minggu kemudian. Pemeriksaan IVA bisa dilakukan oleh dokter umum, perawat atau bidan yang terlatih, dan tidak membutuhkan ahli patologi. Jika tes
IVA hasil negatif, pasien bisa segera mengetahui tanpa harus kembali ke dokter untuk mengetahui hasilnya. Pasien yang tinggal di daerah terpencil bisa langsung mengetahui hasil pemeriksaaan IVA tanpa harus mengunjungi fasilitas kesehatan lagi. Metode skrining dengan teknik IVA ini cocok untuk daerah terpencil. IVA mempunyai peran dalam skrining kanker serviks pada negara tertinggal dan menjadi alternatif teknik untuk skrining karena sederhana, mudah, perlakukan cepat, efektif, murah, dan hasilnya cepat diketahui.

\section{SIMPULAN}

Skrining kanker serviks dengan pemeriksaan Pap smear di Puskesmas Tanah Kali Kedinding Surabaya dan Rumah Sakit Mawadah Mojokerto menunjukkan bahwa angka prevalensi lesi prekanker yaitu $1,4 \%$. Pemeriksaan IVA menunjukkan hasil positif semu yang disebabkan oleh proses keradangan atau infeksi pada serviks.

\section{UCAPAN TERIMA KASIH}

Terima kasih disampaikan kepada Universitas Airlangga yang telah memberikan dana untuk pelaksaan kegiatan ini dengan sumber biaya Bantuan Operasional perguruan Tinggi Negeri (BOPTN) tahun 2014, Puskesmas Tanah Kali Kedinding Kenjeran Surabaya, dan Rumah Sakit Mawadah Mojokerto.

\section{DAFTAR PUSTAKA}

1. GLOBOCAN, Estimated Cancer Incidence, Mortality and Prevalence Worldwide In 2012 International Agency For Research On Cancer. http://globocan.iarc.fr/Pages/fact_sheets_ cancer.aspx. 2012. Diakses tgl 07 April 2015.

2. Bruni L, Barrionuevo-Rosas L, Albero G, Aldea M, Serrano B, Valencia S, Brotons M, Mena M, Cosano R, Muñoz J, Bosch FX, de Sanjosé S, Castellsagué X. ICO Information Centre on HPV and Cancer (HPV Information Centre), Human Papillomavirus And Related Diseases Report INDONESIA Version posted on www.hpvcentre. net in March 20th, 2015, Summary Report 201503-20.

http://www.hpvcentre.net/statistics/reports/IDN.pdf . 2014. Accesed 07 April 2015.

3. Ellenson LH, Pirog EC. The Female Genital Tract Chapter 22. In Robbins and Cotran Pathologic Basis of Disease. 8th Eds. Editor Kumar Abbas Fausto Aster. Philadelphia: Saunders Elsevier; 2010. p. 1017-24. 
4. Berek JS, editors. Berek \& Novak's Ginecology. 14th Eds. New York: Lippincot Williams and Wilkins; 2007. p. 1404-50.

5. Tavassoli FA and Devilee P, edistors. Pathology \& Genetics of Tumors of The Breast and Female Genital Organ. Lyon: IARC Press; 2003. p.259-71.

6. Montag A, Kumar V. The Female Genital System and Breast Chapter 19 in Robbin Basic Pathology. 8th Eds. Editor Kumar Abbas Fausto Mitchel. Philadelphia: Saunders Elsevier; 2010. p. 716-20.

7. IARC \& WHO. IARC Handbooks of Cancer Prevention Vol 10 Cervix Cancer Screening Chapter 2 Screening Test international Agency for Research on Cancer World Health Organization, IARC Press, Lyon, pp 59-116 http://www.iarc.fr/ en/publications/pdfs-online/prev/handbook10/

HANDBOOK10.pdf. 2005. Accessed 10 April 2015.

8. Gupta K, Malik NP, Sharma VK, Verma N and Guota A. Prevalence of cervical dysplasia in western Uttar Pradesh. J Cytol. 2013;30(4):257-62.

9. Altaf FJ. Cervical cancer screening with pattern of pap smear. Review of multicenter studies. Saudi Med J. 2006;27(10):1498-502.
10. Consul S, Agrawal A, Sharma H, Bansal A, Gutch $\mathrm{M}$ and Jain N. Comparative study of effectiveness of Pap smear versus visual inspection with acetic acid and visual inspection with Lugol's iodine for mass screening of premalignant and malignant lesion of cervix. Indian J Med Paediatr Oncol. 2012;33(3):161-5.

11. Vedantham H, Silver MI, Kalpana B, Rekhal C, Karuna BP, Vidyadhari K, Mrudula S, Ronnet BM, Vijayaraghavan K, Ramakrishna G, Sowjanya P, Laxmi S, Shah KV, Gravitt PE and for the CATCH Study Team. Determinants of VIA (Visual Inspection of the Cervix After Acetic Acid Application) Positivity in Cervical Cancer Screening of Women in a Peri-Urban Area in Andhra Pradesh, India. Cancer Epidemiol Biomarkers Prev. 2010; 19(5);1373-80.

12. Saleh HS. Can visual inspection with acetic acid be used as an alternative to Pap smear in screening cervical cancer? Middle East Fertility Society Journal. 2014;19:187-91. 